\title{
A Substantive View of Social Enterprises as Neo-endogenous Rural Development Actors
}

\author{
Lucas Olmedo ${ }^{1}$ (1) $\cdot$ Mary O'Shaughnessy ${ }^{1}$ (I)
}

Accepted: 27 November 2021 / Published online: 20 January 2022

(C) International Society for Third-Sector Research 2021

\begin{abstract}
Social enterprises are recognised as relevant rural development actors. The specific features of social enterprises operating within rural areas (i.e. their relational, socially innovative and multi-stakeholder character and their focus on integrated development) concur with the principles of the neo-endogenous approach to rural development, which stress the potential role of third sector organisations as development actors within governance frameworks. In order to study this phenomenon, that links social enterprises and rural development, we propose a conceptual and methodological framework drawing from Polanyi's socio-economic theory, complemented with the concepts of place, spatial scale and corporate agency. Through the proposed framework, we advocate for a plural vision of the economy, socio-spatial and geopolitical sensitive concepts and overcoming methodological individualism for the study of an increasingly relevant phenomenon such as the participation of third sector organisations like social enterprises in the (neo-endogenous) development of rural areas.
\end{abstract}

Keywords Social enterprises · Neo-endogenous rural development · Polanyi substantive economy · Place . Spatial scale $\cdot$ Corporate agency

Lucas Olmedo

Lucas.Olmedo@umail.ucc.ie

Mary O’Shaughnessy

mary.oshaughnessy@ucc.ie

1 Department of Food Business and Development, Cork University Business School, O'Rahilly Building, University College Cork, Cork, Ireland

\section{Introduction}

Third sector organisations, such as social enterprises, have been increasingly recognised as having the potential to contribute towards rural development due to their provision of locally focused solutions to challenges faced by rural communities such as lack of (basic) services or social isolation (Barraket et al., 2019; Kelly et al., 2019). The shift from government to governance identified by scholars since the 1990s meant a change towards 'a new mode of governing that is no longer enacted solely through the formal, coercive powers of the nation state, but exercised through a range of government and non-governmental actors and entities operating at different spatial scales and across different sectors' (Cheshire 2016, p. 596). Among these actors have been acknowledged of especial relevance those with the capacity to develop networks, leverage resources at different spatial scales, enhance citizen engagement and entrepreneurialism, as they can act as catalysts for local change through collective, networked action (Shucksmith, 2012).

Studies published on social enterprises based in European rural areas show how their characteristics, i.e. strong local focus combined with external relations; multi-stakeholder governance; social entrepreneurial and innovative character, and objective to contribute to integrated development (van Twuijver et al., 2020); concur with the principles of the neo-endogenous approach to rural development, which stress the potential of third sector organisations as development actors within governance frameworks (Gkartzios \& Lowe, 2019). By establishing this link, rural social enterprises are argued to be actors with great potential to contribute to (re)valorise their local territories, to connect the local with the global and/or to 
accommodate external forces into local tailor-made solutions (Chatzichristos et al., 2021; Olmedo et al., 2021).

Despite the increase in research published on rural social enterprises since 2010, the literature that has linked social enterprises and rural development has been mainly descriptive with great scope for theoretical development that can inform empirical research (van Twuijver et al., 2020). This paper presents a conceptual and methodological framework to study this increasingly relevant phenomenon. This framework draws from Polanyi's socioeconomic theory, namely the 'substantive' view of the economy (Polanyi, 1957, 1977), which emphasises the embeddedness of economic actors within their natural and social contexts, the coexistence of three forms of economic integration, i.e. market-exchange, redistribution and reciprocity, and the need to overcome methodological individualism but rather focus on comparative contextualised research (Peck, 2013). However, due to the placebased and relational character of rural social enterprises (Lang \& Fink, 2019) and neo-endogenous development (Gkartzios \& Lowe, 2019), we draw from human and political geography literature to complement Polanyi's socio-economic theory with socio-spatial and geopolitical dimensions through the concepts of place (Agnew, 1987) and spatial scale (Hess, 2004). Finally, in line with the collective and political character of (rural) social enterprises (Laville \& Nyssens, 2001), we draw from critical realist philosophy and realist social theory to complement our framework with the notion of corporate agency (Archer, 2000), which provides a tool to examine the potential/capacity of social enterprises to act as collective entities that articulate shared interests and reproduce and/or transform pre-existing structures to bring about neo-endogenous rural development.

The rest of the paper is structured as follows: section two presents the link between the characteristics of rural social enterprises and the principles of neo-endogenous rural development. Section three presents Polanyi's substantive view and discusses, separately, the main elements of the proposed conceptual and methodological framework for the study of social enterprises as (neo-endogenous) rural development actors. Section four links these elements into a framework that advocates for a plural vision of the economy, the utilisation of socio-spatial and geopolitical sensitive concepts and the rejection of methodological individualism for the study of this growing rural phenomenon. Finally, section five draws some conclusions and suggests future research directions.

\section{Linking Rural Social Enterprises and Neo- endogenous Development}

\section{Social Enterprises Within Rural Areas}

Despite not being a new phenomenon, social enterprises have received increasing attention in the last decades from academics and policymakers as actors that address a variety of challenges faced by current societies, such as the work integration of disadvantage groups, the provision of social and health services or the local development of disadvantaged rural areas (European Commission, 2020). Social enterprises are conceptualised as hybrid organisations that tend to combine social, economic and/or environmental goals through entrepreneurial and innovative means, representing new dynamics within the third sector (Nyssens, 2006).

Rural areas have demonstrated to be a fertile ground for social enterprises (CEIS 2019; van Twuijver et al., 2020). Among the factors that have contributed to this density of social enterprises in rural areas, some can be related to a tradition of mutual self-help, community engagement, density of social networks and entrepreneurial character within rural areas (Bosworth \& Atterton, 2012; Steinerowski \& Steinerowska-Streb, 2012), while others can be related to a scarcity of goods and/or services within these areas due to the unattractiveness of (some) rural locations for private investors looking to maximising their profits and to the consequences of neoliberal policies that have reduced the public provision of infrastructures and services from (some) rural areas in the pursuit of 'effectiveness' of public investment (Steiner \& Teasdale, 2019).

Against this background, studies on rural social enterprises have shown how these organisations have provided previously non-existent solutions to challenges faced by rural areas. Research on rural social enterprises show how these organisations have contributed to providing employment opportunities, especially for disadvantaged groups such as people distant from the labour market due to disabilities and/or long-term unemployment (O'Shaughnessy, 2008; Róbert \& Levente, 2017). This employment is usually linked to the provision of basic services otherwise not available in some rural localities such as (public) transportation, healthcare, eldercare and childcare services or (community) shops that provide basic goods for the local population (Calderwood \& Davies, 2013; Farmer et al., 2012; Kelly et al., 2019; Liddle et al., 2012). Moreover, some studies have pointed to the importance of social enterprises to provide and/or retain (community) assets, such as buildings or other infrastructures, within rural localities (Aiken et al., 2016; Healey, 2015). These services and infrastructures have in turn contributed to the social 
and economic development of rural localities by reducing social isolation, enhancing employment and local spending (Steiner \& Teasdale, 2019). Finally, research on rural social enterprises with primarily environmental goals have shown their contribution to sustainable forestry and agriculture, to community renewable energy, to the conservation of nature and biodiversity or to the promotion of environmental sustainability through educational programmes and recycling initiatives within the local population (Jacuniak-Suda \& Mose, 2014; Ludvig et al., 2018; Morrison \& Ramsey, 2019). However, studies on rural social enterprises show that their distinctiveness lies in that their contributions usually cover concurrently different dimensions of development, hence, in their potential to enhance an integrated development of the territory in which they are based (Olmedo et al., 2019).

Research on rural social enterprises has also shown that the context in which these organisations develop their activities plays an important role in their way of functioning (Steiner \& Teasdale, 2019). The rural contexts provide social enterprises with enabling factors, including the absence or few market competitors, the culture of voluntarism and often the appreciation and support from local communities to the social enterprise, as well as constraining factors, such as the geographic characteristics of isolated rural areas, high transportation costs, limited access to work force and finance, small market size or lack of tailor-made policy support (Mazzei \& Roy, 2017; Steinerowski \& Steinerowska-Streb, 2012).

When compared to urban social enterprises, research has pointed towards an inextricable linkage between social enterprises operating in rural areas and their context (Smith \& McColl, 2016). This linkage concurs with the strong local focus presented by these organisations, which primarily exists to meet otherwise not satisfied needs of the local population or some vulnerable groups within it (van Twuijver et al., 2020). This strong local focus is also reflected in the dependence of rural social enterprises on the collective involvement of the local population in the governance and activities of the enterprise (Healey, 2015). Studies on rural social enterprises suggest that the local attachment of their members has been a key feature for tapping into previously underutilised resources that allowed these organisations to develop their projects (Olmedo et al., 2021; Valchovska \& Watts, 2016).

Despite the importance of this strong local focus, research has also shown how an overreliance and dependence by rural social enterprises on the resources of the local community can limit their capacity to achieve their goals (Vestrum, 2014). In this sense, as rural social enterprises usually operate in resource-constrained environments, they tend to be boundary spanners by engaging in relation to actors from different sectors, such as public institutions, other third sectors organisations or for-profit businesses beyond their area/locality in order to attract human and/or financial resources otherwise not available (Berkes \& Davidson-Hunt, 2007; Richter, 2019). The complementarity between their strong local focus and their engagement in relation to external stakeholders has contributed to the capacity of rural social enterprises to harness a wide range of otherwise untapped resources (Healey, 2015). These range from material resources such as buildings different financial streams such as bank loans, donations, market sales or grants; labour either paid and/or volunteer; but also to more intangible resources such as social capital, ideas, skills or expertise (Aiken et al., 2016; Morrison \& Ramsey, 2019; Smith \& McColl, 2016). Through the innovative combination of these wide range of resources, rural social enterprises have been acknowledged as resourcefulness actors that contribute to rural development (Barraket et al., 2019).

\section{Rural Social Enterprises as Neo-endogenous Development Actors}

The main features of rural social enterprises demonstrate four themes that support the link between these organisations and the principles of the neo-endogenous approach towards rural development (see Table 1).

First, the neo-endogenous approach proposes a development of rural areas based on harnessing their specific potential by leveraging and (re)valorising (untapped) local resources; however, this perspective also acknowledges that the endogenous potential of each rural area needs to be complemented through external relations that enable levering resources otherwise not available within a specific rural area. Hence, it emphasises the significance of local actors connected to external actors and influences (Cejudo and Navarro, 2020). Rural social enterprises are characterised as actors that concurrently demonstrate a strong local focus and act as boundary spanners through the development of relations with actors external to their localities (Richter, 2019). Therefore, neo-endogenous development and rural social enterprises concur in their relational character of linking the local (endogenous) and the external.

Second, according to the neo-endogenous approach, (social) entrepreneurship and innovation are important means to tackle challenges faced by rural areas (Bock, 2016; Bosworth \& Atterton, 2012). Rural social enterprises have shown their ability to develop new ways of collective organisation and to combine a wide range of resources in such ways that they develop new products, services and/or infrastructure; thus, they enhance innovative solutions to address the challenges that face the rural areas in which they are based (Barraket et al., 2019; Bosworth et al., 
Table 1 Linking rural social enterprises and neo-endogenous development

\begin{tabular}{lll}
\hline Neo-endogenous rural development & $\longleftrightarrow$ & Rural social enterprises \\
\hline $\begin{array}{l}\text { Networks of local actors connected to external influences } \\
\begin{array}{l}\text { Competitiveness based on local assets but also competing } \\
\text { for resources }\end{array}\end{array}$ & Relational & Strong local focus (mission and participation) \\
$\begin{array}{l}\text { (Social) entrepreneurship and innovation } \\
\text { Boundary spanners-external relations }\end{array}$ \\
$\begin{array}{lll}\text { Multi-scalar and multi-sectoral governing arrangements } & \text { (Social) innovation } & \text { New ways of collective organisation } \\
& \text { governance } & \text { Combine wide range of (untapped) resources } \\
\text { Diverse economies } & \text { Integrated development } & \begin{array}{c}\text { Participatory (multi-stakeholder) governance } \\
\text { Cross-sectoral relations (public/state, market and } \\
\text { civil society) }\end{array} \\
\text { Holistic approach-place making } & & \text { development }\end{array}$ \\
\hline
\end{tabular}

2020). Therefore, neo-endogenous development and rural social enterprises concur in their focus on (social) innovation.

Third, the neo-endogenous approach to rural development stresses the importance of governance frameworks in which actors from different sectors, including third sector organisations, are recognised as legitimate contributors to the development of their rural localities/areas (Chatzichristos et al., 2021). This concurs with the participatory (multi-stakeholder) governance structure usually characteristic of rural social enterprises and their tendency to engage in cross-sectoral relations (Healey, 2015). Therefore, neo-endogenous development and rural social enterprises concur in their emphasis on (multi-stakeholder) governance.

Fourth, the neo-endogenous approach to rural development emphasises the diversity of rural economies and considers development from a holistic perspective which includes economic, social and environmental aspects (Gkartzios \& Lowe, 2019). Research on rural social enterprises has shown that these organisations often address, concurrently, different dimensions of development (Olmedo et al., 2019). Hence, rural social enterprises tend to contribute to an integrated development of their areas/ localities in line with neo-endogenous approach principles.

These commonalities present social enterprises as potential key actors to contribute to neo-endogenous rural development. Beyond these descriptive linkages based on a review of previous research, ${ }^{1}$ this paper aims to provide a theoretical and methodological framework that establishes a solid ground to inform empirical research on this increasingly relevant topic (van Twuijver et al., 2020).

\footnotetext{
1 The literature reviewed on rural social enterprises refers to studies conducted in Europe, North America and Australia ('global north'). The authors acknowledge a potential bias towards rural social enterprises operating in 'developing/global south' countries, see also "Conclusions, limitations and future research directions" section.
}

\section{Polanyi's Substantive View for the Study of Social Enterprises as Neo-endogenous Rural Development Actors}

Scholars from both the field of social enterprises (Nyssens, 2006; Roy \& Grant, 2019) and neo-endogenous rural development (Ray, 2006) have separately stressed the relevance of the work of the economic historian/anthropologist Karl Polanyi for analysing these phenomena. Polanyi's works provide a critique to the 'formal' view of the economy advocated by neoclassic economics (Polanyi, 1957, 1977, 2001 [1944]). This 'formal' view 'equate[s] the human economy with its market form' (Polanyi, 1977, p. 20; see also Block \& Somers, 2014, p. 44), bounding the study of economic behaviour to those interactions occurring within or in relation to the market which is considered as the main sphere for assuring the provision of the goods and services needed and/or demanded by society (Polanyi, 1977). Hence, economic relations are separated from other aspects such as social relations and structures, nature or the role of government, which are only studied in relation to the 'good functioning' of the market, occupying a subordinated role in economic studies (Krippner, 2001). From a methodological perspective, the 'formal' view aims to establish universal laws that can explain how the market and (individual) economic behaviour function (Polanyi, 1977). The focus lies on the (rational) choices made by individual economic actors, such as (social) entrepreneurs, who based on their preferences, try to reach their goals through the selection of optimal means, within a context of perfect information and competition (Beckert, 2003). According to Polanyi, this 'formal' view represents an ahistorical, narrow and incomplete approach towards the economy and economic relations as it lies in an 'economistic fallacy' which leaves aside real economic relations that represents forms of economic integration different from the market, such as 
these of reciprocity and redistribution (Polanyi, 2001 [1944]), and it focuses on the study of individual (market) behaviour isolated from its context (Polanyi, 1977).

In contrast, Polanyi proposed a 'substantive' view of the economy to '[yield] the concepts that are required by the social sciences for an investigation of all the empirical economies' (Polanyi, 1957, p. 244). From the 'substantive' view, economic actors and relations are 'embedded and enmeshed in institutions, economic and noneconomic. The inclusion of the noneconomic being vital' (Polanyi, 1957, p. 250). Therefore, this view focuses on the relations of humans (in plural not a single individual) with others in society (humans) and nature (non-humans) to provide their livelihood (Gemici, 2008) and on the embeddedness of economic actors within specific institutional arrangements that shape these relations (Polanyi, 1957), see Table 2.

\section{Embeddedness: Beyond Social Ties/Networks of Market Actors}

The emphasis of the 'substantive' view on the embeddedness of economic actors and relations within society and nature concurs with a conceptualisation of social enterprises which stresses the direct relation between their economic activity and their social, economic and/or environmental missions, thus not being possible to disconnect one from the other (Roy \& Grant, 2019). Moreover, through the concept of embeddedness the 'substantive' view stresses the relevance of the context for the study of economic relations and actors which concur with the neoendogenous approach to rural development which seeks 'to place development and the economy firmly in a context that is, at once, social and local (territorial)' (Ray, 2006, p. 279).

Despite being first attributed within the social sciences to Polanyi (Block \& Somers, 2014), the concept of embeddedness has been popularised since Granovetter's (re)formulation. In a seminal article, Granovetter (1985) argued that economic behaviour cannot be explained by individuals and groups/organisations who act isolated from each other taking rational choices (referring to neoclassical economics), but that neither could it be explained by rigid social structures which determine the behaviour of individuals (referring mainly to Parson's functionalism although also including Polanyi). He claimed instead that the economic behaviour of actors is embedded and therefore influenced by concrete ongoing systems of social relations and networks that are continuously shaped (Granovetter, 1985, p. 487).

Based on this perspective, different studies have focused on the influence of the structure, strength, density or geographical diversity of social ties/networks on the behaviour of economic actors, including rural social entrepreneurs (Richter, 2019; Vestrum, 2014). Despite the importance of these studies in showing the relevance of social ties/networks for the study of economic behaviour, Granovetterian conceptualisations of embeddedness have been criticised for being narrow and atomistic (Krippner, 2001) as first, they do not critically examine the market but assume and correlate it to the field where economic action happens, with the other forms of economic integration (usually) being ignored (Dale, 2010). Second, they single out what is considered the most relevant characteristic for linking the social and economic spheres, i.e. the social ties/networks of individual (social) entrepreneurs, usually neglecting other features such as socio-spatial and geopolitical aspects that contribute to shape economic relations (Oinas, 1997) and economic entities such as social enterprises characterised by their collective and cooperative dynamics that align with democratic economic principles (Laville, 2014).

\section{Three Forms of Economic Integration: Market- Exchange, Redistribution and Reciprocity}

Despite acknowledging the importance of social ties/networks, to provide a nuanced understanding of rural social enterprises as neo-endogenous development actors, we argue for the relevance of the three forms of economic integration that according to Polanyi (1977) can be found within the economy, i.e. reciprocity, redistribution and market-exchange (Polanyi, 2001 [1944], pp. 45-58; 1957, pp. 250-266; 1977, pp. 35-43).

Reciprocity refers to relations of mutuality between members of a group/community and/or between different groups/organisations. These relations are characterised by the expectation that every counterpart contributes to an exchange of resources based on the social bonds and tacit agreements that exist among them (Laville \& Nyssens,
Table 2 The 'formal' and 'substantive' views of the economy

\begin{tabular}{lll}
\hline & 'Formal' economy & 'Substantive' economy \\
\hline Human nature & Homo economicus & Homo socius \\
Level of analysis & Individual choice & Supra-individual \\
Motivation in economic life & Scarcity-induced & Procurement of material means \\
Object of analysis & Market-exchange, regularities & Livelihood, empirical economy \\
\hline
\end{tabular}

Based on Gemici (2008, p. 22) 
2001; Polanyi, 1957). In the case of inter-group reciprocal relations, they can occur between two groups but these are 'not restricted to duality' (Polanyi, 1957, p. 252), as multiple reciprocity between different groups is likely to happen, especially in larger communities such as, for example, reciprocal exchanges among various third sector, community and voluntary organisations within a rural locality. Allocation of resources based on reciprocity relations usually takes non-monetary forms, such as volunteer labour or in-kind donations, but can also include monetary resources such as sponsorship/monetary donations.

Redistribution refers to relations characterised by centricity; therefore, a central point/authority is in charge of collecting resources and further (re)distributes them to the population, including groups/organisations (Polanyi, 1957, p. 254). This central institution is usually related to a public authority that works at the society level, for example the role of the (welfare) state in contemporary European democracies; consequently, redistribution is typically related to the public sphere. However, redistribution can also originate from private institutions and at smaller scales, evident in the examples of private foundations and their distribution (of some) of the surplus generated by corporations or in the case of social enterprises which (partially) subsidise the cost of some of their services for those who are financially vulnerable from the profits obtained from the sale of goods and/or services (Laville \& Nyssens, 2001).

Market-exchange refers to relations developed within a price-making market system. Two principal elements define markets as institutions that regulate this form of integration, first, the presence of demand and supply. Second, a price-making system characterised by competition that determines the rate at which goods and/or services are exchanged; thus, these rates are not fixed but they fluctuate. Moreover, within a market-exchange system, mostly every element is converted into a commodity that can be bought and sold and relationships are based for the sake of commodities and the goal of obtaining profits (Dale, 2010). These market-exchange relations take form of monetary exchanges in compensation of the purchase of a product and/or service.

These three forms of economic integration tend to coexist within each specific context, in this sense, their incorporation within the analytical framework serves to the purpose of overcoming a 'market fundamentalist' view for the study of economic actors including third sector organisations (Adaman \& Madra, 2002; Block \& Somers, 2014). Social enterprises have proved a tendency towards leveraging and mixing market and non-market resources deriving from market-exchange, redistribution and reciprocity relations (Defourny et al., 2020). In the same line, in a seminal commentary about neo-endogenous rural development, Ray (2006) stressed the alignment of this approach with the 'substantive' view to the economy and with the three forms of economic integration proposed by Polanyi, stating that studies of neo-endogenous rural development are concerned

"with how these relations [reciprocity, redistribution and market-exchange] manifest themselves at the local and regional level ... [and] how, these factors can be manipulated so as to create the conditions for territorial development" (Ray, 2006, p. 280).

Hence, acknowledging the coexistence, and analytical relevance, of these three forms of economic integration supports a nuanced analysis of the way in which rural social enterprises engage in different types of (socio)economic relations as neo-endogenous development actors.

\section{Geopolitical and Socio-spatial Relations: Spatial Scale and Place}

Since the 1990s there has been an increasing interest from geographers on the work of Polanyi and concepts such as embeddedness (Hess, 2004; Peck, 2013). In a reading of the geographical relevance of the work of Polanyi, Roberts (2018, p. 998) stated that 'the substantive exploration of empirical factors that shape economic life is inherently geographical'. Similarly, Peck (2013) attributes a geographical dimension to Polanyi's work as it deals with the problematic of 'placing the economy' (Amin et al., 2002). Therefore, the 'substantive' view of the economy and related concepts such as (Polanyian) embeddedness denote geographical sensitivity.

Studies on rural social enterprises have stressed the role of rural social entrepreneurs who link different 'regime' (institutional) levels (Lang \& Fink, 2019) and act as embedded intermediaries between their localities and supra-regional networks (Morrison \& Ramsey, 2019; Richter, 2019). These studies show the relevance of looking at geopolitical aspects when analysing the embedded relations of rural social enterprises (Chatzichristos \& Nagopoulos, 2020). In this regard, Hess (2004) recognised the importance of looking at relations embedded at the local level; however, he warned about this excessive localism and argued in favour of a 'multi-scalarity' of embeddedness that links different actors and places (Hess, 2004, p. 176).

In this light, we propose the incorporation through the concept of spatial scale (Hess, 2004) of four geopolitical levels for the study of rural social enterprises as neo-endogenous development actors, i.e. local, regional, national, international. The local level refers to close (geopolitical) proximity, thus to those relations occurring between actors 
within the same locality-village and/or with their rural hinterland. The regional level refers to a territorial unit smaller than the state but larger than a locality, thus to those relations occurring between actors situated in different localities (rural and/or urban) within the same regional geographical and/or politico-administrative boundaries and to those relations with actors/bodies that extend their presence across these regional boundaries, e.g. Regional Authorities. The national level refers to the territorial and administrative unit of the state, thus to those relations occurring between actors situated in different regions within the same state and to those relations with actors/bodies that extend their presence throughout the state, e.g. national government. The international level refers to this that transcends the state, thus to those relations between actors situated in different countries and/or with international bodies. However, the boundaries between these geopolitical levels are porous and they do not constitute fixed categories (Paasi, 2002), as for example nationally and/or internationally designed rural development programmes are (usually) implemented by local and/ or regional bodies, therefore showing the interrelation between these levels.

Furthermore, rural social enterprises have been recognised as organisations that are intrinsically related to the rural context where they are based and operate, denoting their place-based character (Healey, 2015; Smith \& McColl, 2016). These studies show the relevance of exploring rural social enterprises through the concept of place to analyse how these organisations are shaped by, and contribute to shaping, their contexts (Guthey et al., 2014; Mazzei, 2017). The concept of place refers to social relations, material objects, meanings and identities that comes together in specific times producing unique geographically located entities and meaningful locations (Cresswell, 2004). Moreover, places are not fixed entities with essential features but they are constantly shaped by the interrelations among different actors and defined in relation to other places, not isolated from them (Massey \& Jess, 1995). From a political-geography perspective, Agnew (1987) stated that places are constituted by three interrelated aspects, i.e. location, locale and sense of place. Location refers to geographical situation, the coordinates (site) within a map, topography and natural features. Locale refers to the material (including technological) and institutional settings in which social relations occur. These include buildings, streets, land, amenities, workspaces, social media sites and institutional frameworks (Hudson, 2001). Sense of place refers to the meaning that people attach to a place. This more symbolic aspect of a place can refer to individual sentiments/feelings and/or to collective sentiments/feelings shared by (larger) groups of people, as expressed, for example, by a collective sense of belonging and/or attachment towards a locality (Massey \& Jess, 1995).

Hence, complementing the concept of embeddedness with those of spatial scale and place provides an analytical tool to study how social enterprises engage with actors and institutions at different geopolitical levels and with sociospatial aspects of their rural context when acting as neoendogenous development actors.

\section{Methodological Substantivism and Corporate Agency}

The 'substantive' view implies a methodological critique of individualist and formalist approaches to the study of economic actors, including those within the third sector (Adaman \& Madra, 2002). From a 'substantive' approach, economic relations of reciprocity, redistribution and/or market-exchange relations refer to institutionalised relations, thus characterised by a certain level of continuity and stability (Maier \& Simsa, 2020; Polanyi, 1957). From this view, economic relations cannot be explained by the mere aggregate of the individual behaviours of actors guided by their personal attitudes; however, they are associated with specific (supporting) structures that spring from 'collective actions of persons in structured situations' (Polanyi, 1977, p. 37). These structures constitute a different entity, with its own emergent properties, which can be differentiated from the sum of its parts (Elder-Vass, 2010 in O'Mahoney \& Vincent, 2014) and which shape, although not determine, (socio-)economic relations (Polanyi, 1957).

The 'substantive' approach to the study of economic actors and relations aligns with critical realists' social theorists for whom actors as agents are conditioned, but not determined, by certain (pre-existing) structures which are reproduced and/or transformed by the relations among different actors over time (Archer, 1995; Danermark et al., 2002; Sayer, 1992). Therefore, the alignment of Polanyi's 'substantive' view of the economy with (critical) realism (Despain, 2011) entails three methodological principles for the study of social enterprises as neo-endogenous rural development actors. In the first instance, the importance attached to the context entails the study of this phenomenon through deeply contextualised empirical studies that can be explained through an iterative engagement between theory and the empirical material gathered (Sayer, 1992). Second, critical realism assumes an analytical duality between structure and agency that separates it from others perspectives that conflate these, such as Gidden's structuration theory (Archer, 2000). Therefore, from this perspective pre-existing structures condition (socio-)economic behaviour; however, these structures are not permanent but they are reproduced and/or transformed into different structures by the relations among different actors 
over time. Third, for actors, in our case rural social enterprises, to be(come) agents of change they need to act as 'corporate agents' (Archer, 2000, pp. 260-270).

According to Archer (2000, pp. 260-270), corporate agents are differentiated from primary agents, the latter represent subjects (individuals or groups) that share some similar features but lack strategic organisation for developing collective action. However, corporate agents represent 'organised interest groups... who are aware of what they want, can articulate it to themselves and to others and have organised in order to obtain it and can engage in concerted action' (Archer, 2000, p. 265). Corporate agents articulate shared interests and (consciously) promote collective action trying to influence decision-making; they do so by interacting strategically with other corporate agents. Thus, these corporate agents act 'in a manner which cannot be construed as the summation of individuals' self-interest' (Archer, 2000, p. 266). Due to their collective character, their usual engagement with the local population and in external relations with other actors and their strategic aim to contribute to the (integrated) development of their rural localities, we argue that social enterprises have the potentiality to act as corporate agents when contributing to neoendogenous rural development.

\section{Towards a Theoretical and Research Framework for the Study of Rural Social Enterprises as Neo- endogenous Development Actors}

Based on the concepts that have been discussed so far, this section puts forwards a theoretical and research framework for the study of social enterprises as neo-endogenous rural development actors (see Fig. 1).

Polanyi's 'substantive' view of the economy offers an appropriate overarching theoretical lens through which to explore the phenomenon of social enterprises as neo-endogenous rural development actors as it stresses the embeddedness of economic actors and relations within their specific historical, social and territorial contexts (Peck, 2013). This view concurs with the hybrid character of (rural) social enterprises which shows an intrinsic relation between their social and economic dimensions (Roy \& Grant, 2019) and also relates to their tendency to mix market and non-market resources (Defourny \& Nyssens, 2017). Therefore, we argue for adopting a plural approach towards the study of the (socio-)economic relations in which rural social enterprises engage, based on the three forms of economic integration as proposed by Polanyi (1977), i.e. reciprocity (mutuality), redistribution (centricity) and market-exchange (competition).

Rural social enterprises tend to hybridise these different forms of economic integration, represented by the intersection of market, redistribution and reciprocity in Fig. 1. As an example of this, some rural social enterprises providing basic services, such as childcare, tend to mix the direct payment of some users (at market rate) with the partial subsidisation of fees, by the government, of those with less economic means; therefore, intersecting market and redistribution socio-economic relations within the service operated by the rural social enterprises. Moreover, rural social enterprises often benefit from reduced prices in the purchase of products and/or services from local business/SMEs, for example, when organising local community festivals or undertaking some construction works. These reduced market prices are linked with the reciprocal relations developed by the social enterprises with these local businesses, which perceive the activities of the social enterprises as a benefit for the whole community, including their own businesses, as they enhance community vibrancy and attract individuals to spend in the businesses of the locality. In this occasion, market and reciprocity relations intersect in the work of rural social enterprises. The specific combinations and hybridisation of these 'substantive' (socio-)economic relations are key for the capacity of rural social enterprises to leverage the resources needed to achieve their goals, thus to bring about change and innovation contributing to neo-endogenous development.

Furthermore, the embeddedness, advocated by the 'substantive' view, concurs with the focus of rural social enterprises on the needs of their local population (van Twuijver et al., 2020). Previous literature has primarily linked the concept of embeddedness with the social ties/ networks of rural social entrepreneurs (Richter, 2019; Vestrum, 2014). However, based on the tendency of rural social enterprises to engage in relation to actors and institutions within, and beyond, their localities and their placebased character (Lang \& Fink, 2019), we argue for the relevance of looking to the embeddedness of these organisations through spatially sensitive concepts (Oinas, 1997). This is done through the concept of spatial scale (Hess, 2004), which allows to focus on the relations in which rural social enterprises engage in with other actors at different geopolitical levels, i.e. international, national, regional and local. In this regard, the study of the relations in which rural social enterprises engage with other rural development actors such as local businesses and other third sector organisations; municipal, regional, national governments and public institutions and international funding bodies and/or social movements can (partially) explain the capacity of these organisations to leverage a wide range of resources and to contribute to a neo-endogenous rural development.

Moreover, the concept of place (Creswell 2004) and its three dimensions, i.e. location, locale and sense of place (Agnew, 1987), allow to focus on the engagement of rural 
'Substantive'View

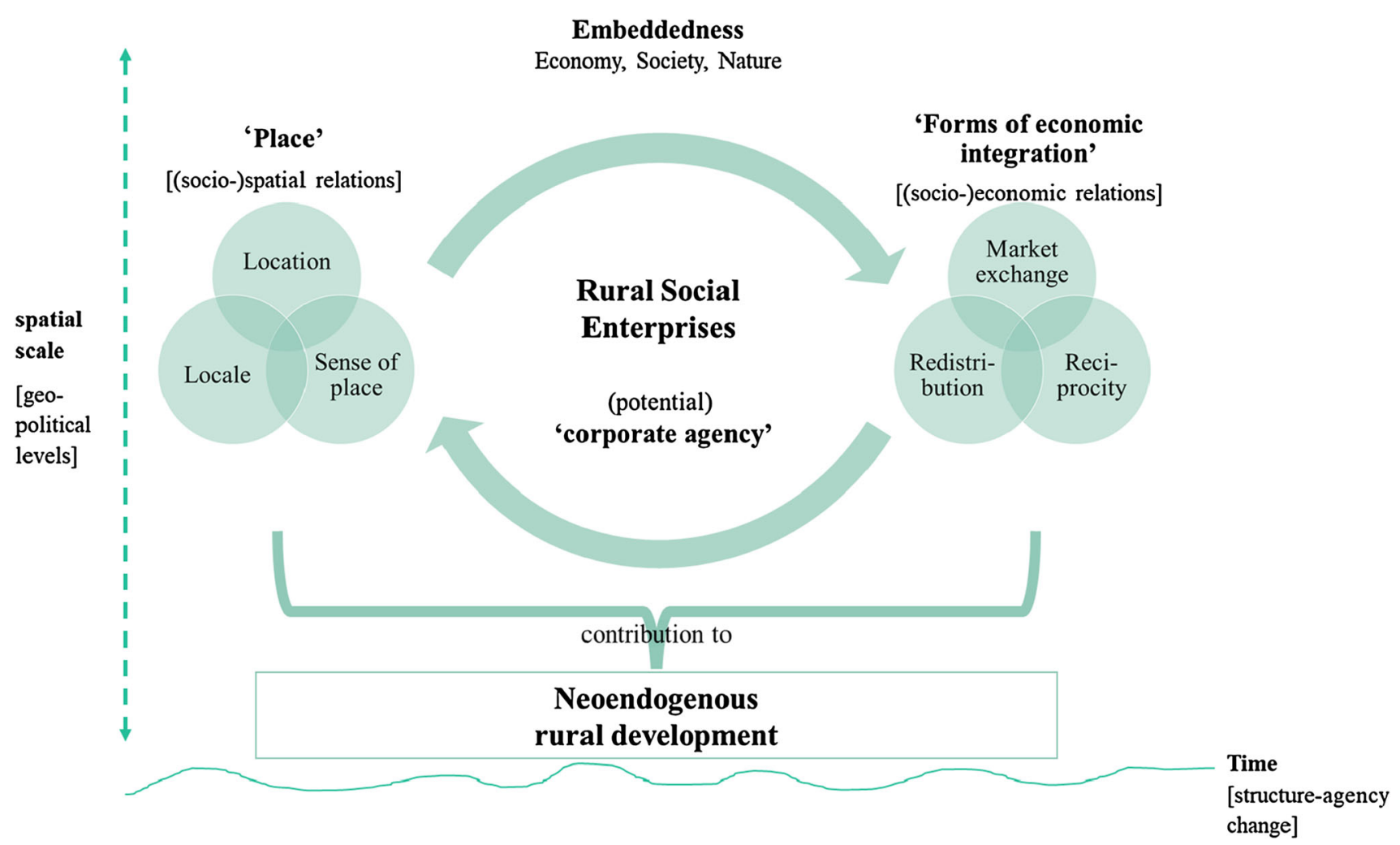

Fig. 1 Towards a theoretical and research framework for the study of rural social enterprises as neo-endogenous development actors

social enterprises with natural, locational, material, institutional and symbolic aspects of their rural context. Although location, locale and sense of place represent differentiated analytical dimensions, the engagement of rural social enterprises tends to intersect among these dimensions, see Fig. 1. As an example, some rural social enterprises revalorise derelict buildings with special symbolic meanings for the community, for example old creameries or schools, turning them into community spaces, e.g. community centres. These renovated material spaces tend to be used by social enterprises and other local organisations to develop activities and services that (potentially) enhance social relations (locale) and a collective sense of belonging (sense of place) within the local population. Therefore, through the work of rural social enterprises locale aspects related to materiality and social relations and sense of place dimensions intersect, contributing to place-making and neo-endogenous development.

It is important to note that within this framework social relations do not constitute a separate (analytical) element. However, within the above-mentioned concepts (embeddedness, forms of integration, place) social relations are always implicit as a central element (Massey \& Jess, 1995;
Polanyi, 1957); therefore, we have added the prefix sociowhen referring to the economic and spatial relations of rural social enterprises. Moreover, spatial scale is considered as a transversal element within this framework as both socio-spatial relations related to place and socio-economic relations related to the different forms of economic integration can occur at different geopolitical levels. As an example, the reciprocity relations which rural social enterprises engage in can be developed with individuals and/or organisations within the same locality but also with the diaspora, thus linking local and international levels.

Moreover, we suggest an interrelation between the socio-economic and socio-spatial relations developed by rural social enterprises (represented by the semi-circular arrows in Fig. 1). Building on the examples provided within this section, in order to revalorise underutilised material assets such as derelict buildings or idle pieces of land, rural social enterprises tend to mobilise and hybridise a wide range of reciprocity, e.g. fundraising; redistribution, e.g. grants from government or local public authorities, and market resources, e.g. bank loans. Therefore, through this hybridisation of forms of economic integration rural social enterprises contribute to place-making. This revalorisation of material aspects of place (buildings, land), in turn, 
contribute to develop activities and services, such as the above-mentioned childcares, community centres, local festivals which also enhance the leverage of reciprocity, e.g. volunteer labour or in-kind donations from the local population; redistribution, e.g. grants or partial subsidisation of the government for some services; and market, e.g. sale of tickets and products at local festivals. This interrelation represents a key aspect due to the place-based nature of, and tendency to hybridise different forms of economic integration by, rural social enterprises and the integrated and rooted development advocated by neo-endogenous rural development.

Finally, this framework focuses on the study of the potential of these organisations to bring about change of certain aspects of their localities, thus their agency capacity. In this regard, this capacity will depend on their ability to be(come) corporate agents (Archer, 2000), thus acting as entities with the ability to articulate their demands and enhance collective action to achieve their goals. However, it is also understood that this capacity is conditioned by the pre-existing contextual features (structures) in which these organisations operate that delimit/condition their possibilities (Archer, 1995). For example, when studying the capacity of rural social enterprises to contribute to neoendogenous development, the local and regional economies where these organisations are based and operate, the connectivity of their places, the (lack of) availability of land and buildings to develop projects and existing ownership structures, the de/centralisation of public institutions and government, internal community conflicts or a limited population/critical mass to draw skills and resources from are important aspects that can influence this corporate agency of rural social enterprises. In this sense and in line with the place-based approach previously advocated, we argue that these (structural) conditions influence the way in which rural social enterprises work, but also that through their work these organisations (can) contribute to the development/change of (some of) these structural aspects, thus to the (re)construction of the places in which they operate (Mazzei, 2017).

\section{Conclusion, Limitations and Future Research Directions}

This paper focuses on an increasingly relevant phenomenon such as the participation of third sector organisations, and more specifically social enterprises, in the neoendogenous development of rural areas (Cejudo \& Navarro, 2020). This increasing participation takes place in different areas such as in the co-production of services (Kelly et al., 2019), the provision of infrastructure (Aiken et al., 2016), the integration of disadvantage workers
(Róbert \& Levente, 2017) or the production of sustainable energy (Morrison \& Ramsey, 2019).

The analysis of the type of activities developed by rural social enterprises and their way of working for achieving their goals reveal that these organisations show characteristics that concur with the principles of neo-endogenous rural development (Gkartzios \& Lowe, 2019; van Twuijver et al., 2020). Hence, rural social enterprises present significant potential as one of the key actors that can work complementary to others such as government, local forprofit business and other third sector organisations for (re)valorising local resources at the same time that reacting to external global forces when pursuing the development of rural areas (Bock, 2016).

However, studies specifically linking social enterprises and rural development are generally descriptive, lacking conceptual frameworks based on socio-economic theory(ies) that guide the analysis of this phenomenon. In this regard, we argue that the 'substantive' view of the economy provides a sound theoretical lens from which to analyse this phenomenon due to its emphasis on the embeddedness of economic relations and actors within society and nature (Polanyi, 1957). Topical phenomena such as climate-change, refugee crisis or the current COVID-19 pandemic evidence that the economy, nature and society are intrinsically related, therefore reinforcing the importance of using theoretical frameworks that acknowledge the relations between these spheres rather than their isolation from each other (Gupta et al., 2015).

Furthermore, the incorporation within the proposed theoretical framework of a plural view towards economic relations, represented by three forms of economic integration (reciprocity, redistribution and market-exchange), together with socio-spatial and geopolitical concepts, such as place and spatial scale, provides nuanced analytical tools for the study of this economic, but not limited to the market, and territorially based, but not bounded, complex phenomenon such as the participation of social enterprises as neo-endogenous development actors (Chatzichristos et al., 2021).

The framework proposed, we argue, can be used to empirically assess the strengths, opportunities and limits of rural social enterprises as neo-endogenous development actors. It offers an approach that encourages an analysis of the engagement of rural social enterprises with different aspects of the places where they are based, the engagement, collaborations and/or competition of rural social enterprises with actors from different sectors and at different spatial scales, the way(s) in which rural social enterprise (strategically) leverage and combine resources, the opportunities and trade-offs of related to the hybrid nature of rural social enterprises or the (lack of) transformative capacity of rural social enterprises within their areas/ 
localities. In addition to supporting the advancement of this academic field, empirical evidence from some of these topics can provide relevant information for practitioners in the field, for example, in terms of organisational means or resource mobilisation, and for policymakers, for example, in terms of tailor-made support for this type of organisations.

The proposed framework is not absent of limitations. In the first instance, the main features of rural social enterprises presented within this paper are based on studies conducted in the so-called global north (Europe, North America and Australia). Despite the use of a theoretical lens, such as the substantive economy, which has been acknowledged as sensitive to capture the nature of social enterprises from the 'global south', for example focusing on collaborative and (informal) reciprocal-solidarity relations (Coraggio et al., 2015), the framework would benefit from the incorporation of empirical evidence, epistemological and further theoretical lenses that link and/or stimulate global south-north dialogues on social enterprises and rural development (Hulgård et al., 2019). Moreover, in the proposed framework householding relations are encompassed within reciprocity relations (Polanyi, 1977). However, the further distinction of householding relations (as a fourth mode of economic integration) presents potential to capture the dynamics of social enterprises operating in more informal ways and/or economies and to understand the significance of the domestic domain and the contribution of women to the substantive economy (Hillenkamp and Dos Santos, 2019).

Finally, we acknowledge rural social enterprises, not as a panacea nor a substitute but, as potential partners for other relevant actors contributing to rural development. We suggest that empirical research based on sound theoretical bases can contribute to answering and/or guiding political questions such as whether or not social enterprises, and social economy organisations more generally, constitute a safety net for neoliberalism and/or actual alternative ways of (rural) development (Roy \& Grant, 2019).

Acknowledgements The author's would like to thank you two anonymous reviewers for their comments to improve this paper.

Funding This research has been funded through the European Union's Horizon 2020 research and innovation programme under the Marie Sklodowska-Curie Innovative Training Network Grant Agreement No. 721999.

\section{Declarations}

Conflict of interest The authors have no relevant financial or nonfinancial interests to disclose.

\section{References}

Adaman, F., \& Madra, Y. M. (2002). Theorizing the "Third Sphere": A critique of the persistence of the "Economistic Fallacy." Journal of Economic Issues, 36(4), 1045-1078.

Agnew, J. (1987). A theory of place and politics. In J. Agnew (Ed.), Place and politics: The geographical mediation of state and society (pp. 25-43). Allen and Unwin.

Aiken, M., Taylor, M., \& Moran, R. (2016). Always look a gift horse in the mouth: Community organisations controlling assets. VOLUNTAS: International Journal of Voluntary and Nonprofit Organizations, 27(4), 1669-1693.

Amin, A., Cameron, A., \& Hudson, R. (2002). Placing the social economy. Routledge.

Archer, M. S. (1995). Realist social theory. Cambridge University Press.

Archer, M. S. (2000). Being human: The problem of agency. Cambridge University Press.

Barraket, J., Eversole, R., Luke, B., \& Barth, S. (2019). Resourcefulness of locally-oriented social enterprises: Implications for rural community development. Journal of Rural Studies, 70, $188-197$.

Beckert, J. (2003). Economic sociology and embeddedness. How shall we conceptualize economic action? Journal of Economic Issues, 37, 769-787.

Berkes, F., \& Davidson-Hunt, I. J. (2007). Communities and social enterprises in the age of globalization. Journal of Enterprising Communities, 1(3), 209-221.

Block, F., \& Somers, M. (2014). The power of market fundamentalism: Karl Polanyi's critique. Harvard University Press.

Bock, B. B. (2016). Rural marginalisation and the role of social innovation: A turn towards nexogenous development and rural reconnection. Sociologia Ruralis, 56, 552-573.

Bosworth, G., \& Atterton, J. (2012). Entrepreneurial in-migration and neoendogenous rural development. Rural Sociology, 77, 254-279.

Bosworth, G., Price, L., Hakulinen, V., \& Marango, S. (2020). Rural social innovation and neo-endogenous rural development. In E. Cejudo \& F. Navarro (Eds.), Neoendogenous development in European rural areas (pp. 21-32). Springer Geography.

Calderwood, E., \& Davies, K. (2013). Localism and the community shop. Local Economy, 28(3), 339-349.

Cejudo, E., \& Navarro, F. (Eds.). (2020). Neoendogenous development in European rural areas. Springer Geography.

Chatzichristos, G., \& Nagopoulos, N. (2020). Social entrepreneurship and institutional sustainability: Insights from an embedded social enterprise. VOLUNTAS: International Journal of Voluntary and Nonprofit Organizations, 31(3), 484-493.

Chatzichristos, G., Nagopoulos, N. and Poulimas, M. (2021). Neoendogenous rural development: A path toward reviving rural Europe. Rural Sociology, [online]. Retrieved April 20, 2021, from https://onlinelibrary.wiley.com/doi/abs/10.1111/ruso.12380

Community Enterprise in Scotland (CEIS). (2019). Social Enterprises in Scotland. Census 2019. Retrieved February 20, 2021, from https://socialenterprisecensus.org.uk/wp-content/themes/cen sus19/pdf/2019-report.pdf

Coraggio, J., Eynaud, P., Ferrarini, A., Filho, G. C., Gaiger, L. I., Hillenkamp, I., Kitajima, K., Laville, J. L., Lemaitre, A., Sadik, Y., Veronese, A., \& Wanderley, F. (2015). The theory of social enterprise and pluralism: solidarity-type social enterprise. In J. L. Laville, D. Young, \& P. Eynaud (Eds.), Civil society, the third sector and social enterprise governance and democracy ( $\mathrm{pp}$. 234-249). Routledge.

Cresswell, T. (2004). Place: A short introduction. Blackwell Pub.

Dale, G. (2010). Karl Polanyi: The limits of the market. Polity. 
Danermark, B., Ekström, M., Jakobsen, L., \& Karlsson, J. C. (2002). Explaining society: Critical realism in the social sciences. Routledge.

Defourny, J., \& Nyssens, M. (2017). Fundamentals for an international typology of social enterprise models. VOLUNTAS: International Journal of Voluntary and Nonprofit Organizations, 28(6), 2469-2497.

Defourny, J., Nyssens, M., \& Brolis, O. (2020). Testing social enterprise models across the world: Evidence from the "International comparative social enterprise models" (ICSEM) project. Nonprofit and Voluntary Sector Quarterly, in press [online]. Retrieved April 29, 2021, from http://hdl.handle.net/2078.1/ 232369

Despain, H. G. (2011). Karl Polanyi's metacritique of the liberal creed: Reading Polanyi's social theory in terms of dialectical critical realism. Journal of Critical Realism, 10(3), 277-302.

European Commission. (2020). Social Enterprises and their Ecosystems in Europe. Comparative synthesis report. Publications Office of the European Union

Farmer, J., Hill, C., \& Muñoz, S. A. (2012). Community coproduction: Social Enterprise in remote and rural communities. Edward Elgar.

Gemici, K. (2008). Karl Polanyi and the antinomies of embeddedness. Socio-Economic Review, 6(1), 5-33.

Gkartzios, M., \& Lowe, P. (2019). Revisiting neo-endogenous rural development. In M. Scott, N. Gallent, \& M. Gkartzios (Eds.), The Routledge companion to rural planning. A handbook for practice (pp. 159-169). Routledge.

Granovetter, M. (1985). Economic action and social structure: The problem of embeddedness. The American Journal of Sociology, 91(3), 481-510.

Gupta, J., Pouw, N., \& Ros-Tonen, M. (2015). Towards an elaborated theory of inclusive development. European Journal of Development Research, 27(4), 541-559.

Guthey, G. T., Whiteman, G., \& Elmes, M. (2014). Place and sense of place: Implications for organizational studies of sustainability. Journal of Management Inquiry, 23(3), 254-265.

Healey, P. (2015). Civil society enterprise and local development. Planning Theory \& Practice, 16(1), 11-27.

Hess, M. (2004). 'Spatial' relationships? Towards a reconceptualization of embeddedness. Progress in Human Geography, 28(2), 165-186.

Hillenkamp, I., \& Dos Santos, L. (2019). The domestic domain within a post-colonial, feminist reading of social enterprise: towards a substantive, gender-based concept of solidarity enterprise. In P. Eynaud, J. L. Laville, L. L. Dos Santos, S. Banerjee, H. Hulgard, \& F. Avelino (Eds.), Theory of social enterprise and pluralism: SocialMovements, Solidarity Economy, and Global South (pp. 90-115). Routledge.

Hudson, R. (2001) Producing places. Guildford Press.

Hulgård, L., Avelino, F., Eynaud, P., \& Laville, J. L. (2019). Deepening the theoretical and critical debate through a North South dialogue. In P. Eynaud, J. L. Laville, L. L. Dos Santos, S. Banerjee, H. Hulgård, \& F. Avelino (Eds.), Theory of social enterprise and pluralism: Social movements, solidarity economy, and global south (pp. 225-240). Routledge.

Jacuniak-Suda, M., \& Mose, I. (2014). Social enterprises in the Western Isles (Scotland)-Drivers of sustainable rural development? Europa Regional, 19(2), 23-40.

Kelly, D., Steiner, A., Mazzei, M., \& Baker, R. (2019). Filling a void? The role of social enterprise in addressing social isolation and loneliness in rural communities. Journal of Rural Studies, 70, $225-236$.

Krippner, G. R. (2001). The elusive market: Embeddedness and the paradigm of economic sociology. Theory and Society, 30(6), $775-810$.
Lang, R., \& Fink, M. (2019). 'Rural social entrepreneurship: The role of social capital within and across institutional levels. Journal of Rural Studies, 70, 155-168.

Laville, J. L. (2014). The social and solidarity economy: A theoretical and plural framework. In J. Defourny, L. Hulgård, \& V. Pestoff (Eds.), Social enterprise and the third sector. Changing European landscapes in a comparative perspective (pp. 102-113). Routledge.

Laville, J. L., \& Nyssens, M. (2001). The social enterprise. Towards a theoretical socio-economic approach. In C. Borzaga \& J. Defourny (Eds.), The emergence of social enterprise (pp. 312-332). Routledge.

Liddle, J., McElwee, G., \& Disney, J. (2012). Rural transport and social inclusion: The DalesBus initiative. Local Economy, 27(1), 3-18.

Ludvig, A., Wilding, M., Thorogood, A., \& Weiss, G. (2018). Social innovation in the Welsh Woodlands: Community based forestry as collective third-sector engagement. Forest Policy and Economics, 95, 18-25.

Maier, F. and Simsa, R. (2020) How actors move from primary agency to institutional agency: A conceptual framework and empirical application. Organization, in press [online]. Retrieved May 05, 2021, from https://journals-sagepub-com.ucc.idm.oclc. org/doi/10.1177/1350508420910574

Massey, D. B., \& Jess, P. M. (1995). A place in the world? Places, cultures and globalization. Oxford University Press.

Mazzei, M. (2017). Understanding difference: The importance of "place" in the shaping of local social economies. VOLUNTAS: International Journal of Voluntary and Nonprofit Organizations, 28(6), 2763-2784.

Mazzei, M., \& Roy, M. J. (2017). From policy to practice: Exploring practitioners' perspectives on social enterprise policy claims. VOLUNTAS: International Journal of Voluntary and Nonprofit Organizations, 28(6), 2449-2468.

Morrison, C., \& Ramsey, E. (2019). Power to the people: Developing networks through rural community energy schemes. Journal of Rural Studies, 70, 169-178.

Nyssens, M. (Ed.). (2006). Social enterprise-At the crossroads of market. Public Policies and Civil Society.

O'Mahoney, J., \& Vincent, S. (2014). Critical realism as an empirical project: A begginer's guide. In P. K. Edwards, J. O'Mahoney, \& S. Vincent (Eds.), Studying organizations using critical realism: A practical guide (pp. 1-20). Oxford University Press.

Oinas, P. (1997). 'On the socio-spatial embeddedness of business firms. Erdkunde, 51(1), 23-32.

Olmedo, L., van Twuijver, M., \& O’Shaughnessy, M. (2019). Community-Based Social Enterprises Fostering Inclusive Development in Peripheral European Rural Areas. United Nations Social and Solidarity Economy Knowledge Hub for the Sustainable Development Goals [online]. Retrieved February 20, 2021, from https://knowledgehub.unsse.org/knowledge-hub/ community-based-social-enterprises-fostering-inclusive-develop ment-in-peripheral-european-rural-areas/

Olmedo, L., van Twuijver, M., \& O'Shaughnessy, M. (2021). Rurality as context for innovative responses to social challenges-The role of rural social enterprises. Journal of Rural Studies. https:// doi.org/10.1016/j.jrurstud.2021.04.020 in Press.

O'Shaughnessy, M. (2008). Statutory support and the implications for the employee profile of rural based Irish work integration social enterprises (WISEs). Social Enterprise Journal, 4(2), 126-135.

Paasi, A. (2002). Place and region: Regional worlds and words. Progress in Human Geography, 26(6), 802-811.

Peck, J. (2013). For Polanyian economic geographies. Environment and Planning A, 45(7), 1545-1568.

Polanyi, K. (1957). The economy as an instituted process. In K. Polanyi, C. M. Arensberg, \& H. W. Pearson (Eds.), Trade and 
market in the early empires: Economies in history and theory (pp. 243-269). Free Press.

Polanyi, K. (1977). The livelihood of man. Academic Press.

Polanyi, K. (2001 [1944]). The great transformation: The political and economic origins of our time (2nd ed.). Reprint Beacon Press.

Ray, C. (2006). Neo-endogenous rural development in the EU. In P. J. Cloke, T. Marsden, \& P. Mooney (Eds.), Handbook of rural studies (pp. 278-291). SAGE Publications.

Richter, R. (2019). Rural social enterprises as embedded intermediaries: The innovative power of connecting rural communities with supra-regional networks. Journal of Rural Studies, 70, 179-187.

Roberts, P. (2018). Karl Polanyi as a spatial theorist. Globalizations, 15(7), 995-1006.

Róbert, T., \& Levente, A. (2017). Social innovations for the disadvantaged rural regions: Hungarian experiences of the new type social cooperatives. Eastern European Countryside, 23(1), $27-49$.

Roy, M. J., \& Grant, S. (2019). The contemporary relevance of Karl Polanyi to critical social enterprise scholarship. Journal of Social Entrepreneurship, 11(2), 1-17.

Sayer, A. (1992). Method in social science (2nd ed.). Taylor \& Francis.
Shucksmith, M. (2012). Future directions in rural development? Carnegie UK Trust.

Smith, A., \& McColl, J. (2016). Contextual influences on social enterprise management in rural and urban communities. Local Economy, 31(5), 572-588.

Steiner, A., \& Teasdale, S. (2019). Unlocking the potential of rural social enterprise. Journal of Rural Studies, 70, 144-154.

Steinerowski, A., \& Steinerowska-Streb, I. (2012). Can social enterprise contribute to creating sustainable rural communities? Using the lens of structuration theory to analyse the emergence of rural social enterprise. Local Economy, 27(2), 167-182.

Valchovska, S., \& Watts, G. (2016). Interpreting community-based enterprise: A case study from rural Wales. Journal of Social Entrepreneurship, 7(2), 211-235.

van Twuijver, M., Olmedo, L., O'Shaughnessy, M., \& Hennessy, T. (2020). Rural social enterprises in Europe: A systematic literature review. Local Economy, 35(2), 121-142.

Vestrum, I. (2014). The embedding process of community ventures: Creating a music festival in a rural community. Entrepreneurship \& Regional Development, 26(7-8), 619-644.

Publisher's Note Springer Nature remains neutral with regard to jurisdictional claims in published maps and institutional affiliations. 